\title{
SISTEM PERINGATAN REAL-TIME BERBASIS TWITTER UNTUK BENCANA KEBAKARAN DI KOTA JAKARTA
}

\author{
A REAL-TIME TWEET BASED WARNING SYSTEM \\ FOR FIRE DISASTER IN JAKARTA CITY \\ Budhi Fatanza Wiratama, \& Muarrkih Yazka Ginang Prasidana
}

Politeknik Statistika STIS

Jalan Otto Iskandardinata No. 64C Jakarta 13330

e-mail : 16.9048@stis.ac.id

Diterima tanggal: 13 Desember 2020 ; diterima setelah perbaikan: 26 Desember 2020 ; Disetujui tanggal: 30 Desember 2020

\begin{abstract}
ABSTRAK
Kepadatan penduduk yang tinggi di perkotaan menimbulkan berbagai masalah sosial dan bencana buatan manusia, salah satu yang paling bermasalah adalah kebakaran. Penanganan kebakaran menjadi semakin sulit untuk wilayah perkotaan seperti Jakarta dengan akses yang terbatas akibat lebar jalan, juga tingkat kemacetan yang tinggi. Di sisi lain, Jakarta memiliki pembangunan teknologi yang tinggi, termasuk penggunaan Twitter sebagai bagian dari big data. Penelitian ini menggunakan tweet yang dibuat oleh para pengguna twitter untuk membangun sebuah sistem peringatan bencana kebakaran berupa peta geografis indikasi kebakaran yang ditampilkan secara real-time atau langsung. Metode yang digunakan mencakup web streaming, web scraping, Support Vector Classifier dan analisis SWOT. Hasil prototipe menunjukkan bahwa titik apil hasil web scraping memiliki kemiripan dengan peta kebakaran yang dikeluarkan oleh BPBD DKI Jakarta pada akhir bulan. Berdasarkan analisis SWOT, penggunaan sistem peringatan berbasis Twitter dapat memaksimalkan pelayanan publik dengan melibatkan masyarakat itu sendiri. Data real-time juga dapat digunakan sebagai bahan pembuatan kebijakan yang cepat dan akurat.
\end{abstract}

Kata kunci: Kebakaran, Twitter, Support Vector Classifier, SWOT.

\section{ABSTRACT}

The high population density of urban areas raises various social problems and man-made disasters, one of the most problematic is fire. Handling fires is becoming increasingly difficult for urban area with limited access due to road widths, also its high congestion in. On the other hand, urban have even more technological options than rural, include the use of Twitter as part of big data. This study uses tweets from twitter user to build a fire disaster early warning system in the form of a real-time geographic map of fire indications. The method used is web streaming, web scraping, Support Vector Classifier and SWOT analysis. The prototype results show that the fire spots from web scraping have similarities with the fire maps issued by BPBD DKI Jakarta at the end of the month. Based on the SWOT analysis, the use of a tweet-based warning system can maximize public services by involving the community itself. Real-time data can also be used as material for fast and accurate policy making.

Keyword: Fires, Twitter, Support Vector Classifier, SWOT.

Sistem Peringatan Real-Time Berbasis Twitter untuk Bencana Kebakaran di Kota Jakarta - Budhi Fatanza Wiratama, \& 


\section{PENDAHULUAN}

Sekitar 55,3 persen dari populasi dunia hidup di wilayah perkotaan (UN, 2018a). Terdapat perpindahan penduduk yang masif dari wilayah pedesaan menuju kota-kota yang sedang berkembang (Sorensen \& Okata, 2011). Hal inilah yang kemudian membuat kehidupan perkotaan identik dengan padatnya penduduk dan hiruk pikuk kehidupan, meski dalam berbagai aspek, sesuatu bisa didapatkan dengan lebih mudah di perkotaan dibanding perdesaan. Sejak tahun 1975, pertumbuhan penduduk perkotaan di negara berkembang meningkat sangat progresif, yang membuatnya harus menghadapi lebih banyak permasalahan (UN, 2018b). Daftar sepuluh kota dengan kepadatan penduduk tertinggi di dunia, ditunjukkan dalam Gambar 1, di mana kebanyakan terletak di negara berkembang (Brodie, 2017). Jakarta, ibukota negara Indonesia menempati peringkat ke-10 di tingkat dunia, dan tingkat ke-3 di Asia Tenggara.

Overcrowding, istilah yang digunakan untuk menggambarkan sangat tingginya kepadatan penduduk, kepadatan perumahan dan kehidupan internal, seringkali menimbulkan gangguan sosial atau bahkan bencana buatan manusia (Thangavel et al., 1987). Sampai hari ini, api masih menjadi penyebab utama kasus kematian perkotaan akibat bencana buatan manusia (McNab, 1970). Api dapat menyebabkan kebakaran pada berbagai bangunan yang memenuhi kawasan kota dan berdampak kompleks, atau yang kemudian disebut dengan bencana kebakaran.

Kebakaran di permukiman padat penduduk di wilayah perkotaan di negara berkembang semakin marak (Jago, 2013). Hal tersebut merupakan hasil dari akumulasi berbagai permasalahan seperti buruknya instalasi listrik, sikap tidak sadar kebakaran, bangunan semipermanen yang padat dan tidak teratur, alat pemadam api yang terbatas, dan jalur evakuasi yang minim. Sebagai kota terpadat di Indonesia, sebanyak 857 kasus kebakaran terjadi di Jakarta pada periode 1 Januari hingga 7 Juli 2019. Secara statistik, kita akan menemukan empat kasus kebakaran setiap harinya di Jakarta (Setiawan, 2019). Kasus kebakaran sepanjang semester I tahun 2019 ini menelan kerugian 137,8 miliar rupiah, dengan korban sebanyak sembilan orang meninggal dunia, 60 orang luka-luka, dan 8.353 orang kehilangan rumah tempat tinggal (Antara, 2019).

Permasalahan kompleks yang dialami daerah perkotaan pada umumnya seperti Jakarta menjadi penyebab membesarnya dampak kebakaran ini. Hanya 50 persen dari seluruh jaringan jalan raya di Jakarta yang dapat diakses oleh mobil pemadam kebakaran selebar tiga meter (Ismawan, 2008). Sebenarnya, masalah tersebut sudah sedikit teratasi dengan inovasi Dinas Pemadam Kebakaran Jakarta dengan menyediakan 110 unit motor pemadam kebakaran yang memiliki keterjangkauan lebih baik dibandingkan truk di beberapa daerah di Jakarta. Sayangnya, rumitnya sistem tata kota di kawasan padat penduduk, serta status Jakarta sebagai kota dengan kemacetan terparah di Asia Tenggara dan ketujuh di dunia dengan skor Indeks Lalu Lintas sebesar 535 (TomTom, 2019), membuat Dinas Pemadam Kebakaran Jakarta menemukan lebih banyak kendala dalam mencapai titik lokasi kebakaran. Sementara waktu merupakan indikator yang sangat penting untuk meminimalkan dampak kebakaran itu sendiri.

Di sisi lain, perkotaan memiliki lebih banyak pilihan teknologi untuk mengatasi berbagai masalah daripada

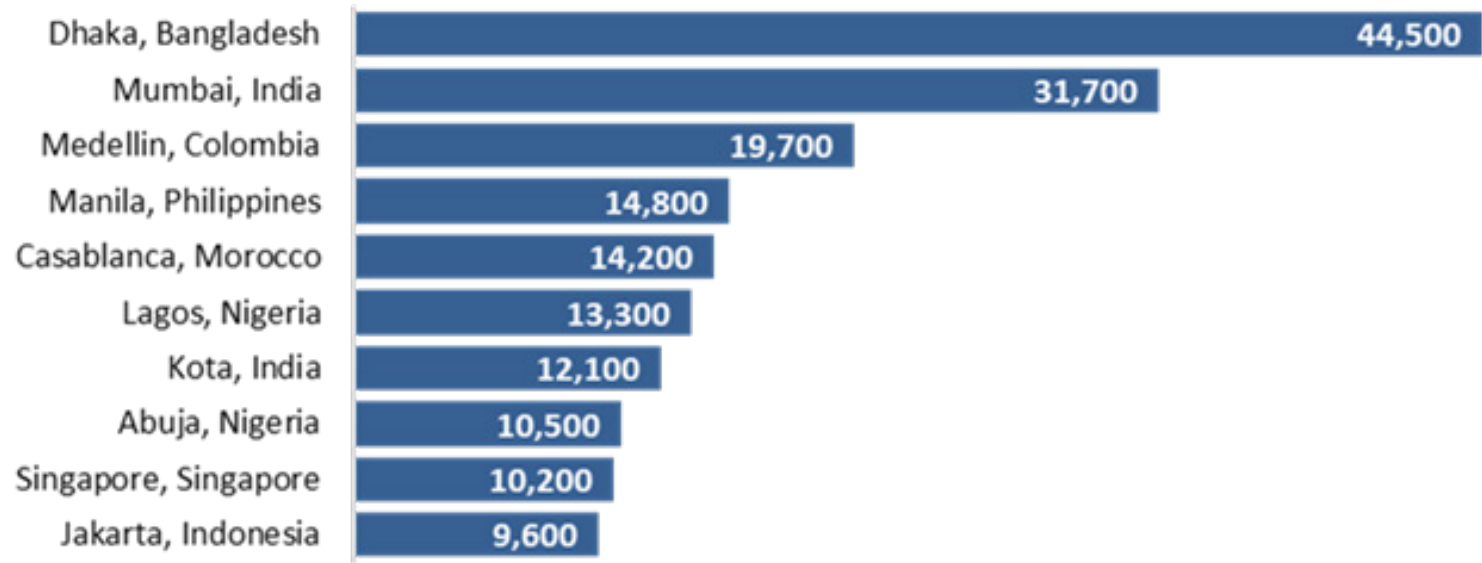

Gambar 1. Kota terpadat di dunia (penduduk per meter persegi) (Brodie, 2017)

Figure 1. Most populous city in the world (population per square meter)

\section{JURNAL RISET JAKARTA, Vol. 13, No 2, NOVEMBER 2020, Hal. 95-104}


daerah pedesaan (Mejía-d \& Dugand, n.d.). Dalam hal ini termasuk internet sebagai komponen utama dari perkembangan teknologi digital. Berdasarkan Publikasi Statistik Telekomunikasi Indonesia 2017 yang dirilis Badan Pusat Statistik, tingkat penetrasi internet penduduk usia lima tahun ke atas di Provinsi DKI Jakarta yang seluruh wilayahnya diklasifikasikan sebagai perkotaan, pada tahun 2017 mencapai 60,65 persen, merupakan yang tertinggi di Indonesia (Badan Pusat Statistik, 2018). Pada Gambar 2 dapat dilihat bahwa terdapat tren pertumbuhan yang menunjukkan tingkat penetrasi pada tahun 2017 mencapai hampir dua kali lipat dari tingkat penetrasi pada tahun 2013.

Akhir-akhir ini, dunia banyak menyadari bahwa Twitter yang merupakan bagian dari Internet memiliki data dalam jumlah besar yang dapat dimanfaatkan, atau dikenal dengan big data. Definisi big data oleh McKinsey Global Institute adalah kumpulan data yang ukurannya di luar kemampuan perangkat lunak basis data pada umumnya untuk menangkap, menyimpan, mengelola, dan menganalisis (Kalyvas \& Overly, 2015). Big data saat ini telah menjadi sumber pengumpulan data yang prospektif. Ketersediaan data dalam volume yang besar, keragaman dan kecepatan yang tinggi, menjadik kekuatan big data sebagai sumber data dasar kebijakan pelayanan publik yang memerlukan pengambilan keputusan yang cepat, aktual, akurat, dan mewakili kebutuhan masyarakat. Twitter membawa data dalam ukuran yang besar secara langsung atau real-time melalui tweet yang dibuat oleh pengguna, juga informasi akun dan koordinat lokasi tempat tweet dibuat. Tweet menurut Jansen et al (2009)

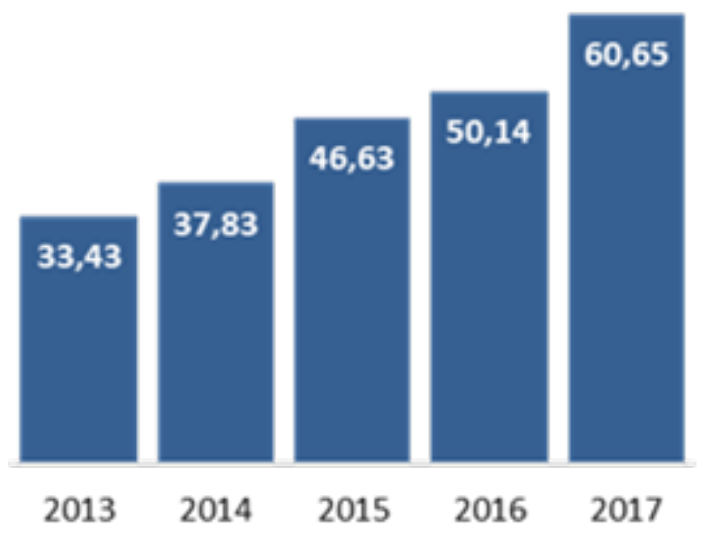

Gambar 2. Penetrasi internet penduduk Provinsi DKI Jakarta tahun 2013-2017 (Badan Pusat Statistik, 2018)

Figure 2. Internet penetration of residents of DKI Jakarta Province 2013-2017 (Central Statistics Agency, 2018) dibuat dengan ber-bagai alasan mulai dari sekedar mengungkapkan perasaan pribadi, pendapat, hingga penyampaian informasi dan berita yang terjadi pada saat itu (Adedoyin-Olowe et al., 2014). Jadi, Twitter menyimpan sebuah peluang besar dalam pemanfaatannya, khususnya bagi warga perkotaan dalam menyelesaikan masalah dalam bencana kebakaran.

Sistem informasi bencana serupa yang sudah tersedia dan dapat diakses secara terbuka untuk wilayah Indonesia adalah petabencana.id. Platform ini dijalankan oleh Yayasan Peta Bencana dengan memanfaatkan penggunaan media sosial dalam situasi darurat untuk mengumpulkan, memilah, dan menampilkan informasi risiko secara real-time (Yayasan Peta Bencana, n.d.). Namun, bencana yang termasuk dalam sistem ini adalah bencana alam yang meliputi banjir, gempa bumi, angin kencang, kebakaran hutan, kabut asap, dan gunung berapi. Padahal, bencana yang terjadi di perkotaan lebih banyak dan kompleks, mencakup bencana-bencana buatan manusia termasuk kebakaran, seperti yang telah disebutkan sebelumnya.

\section{BAHAN DAN METODE}

Penelitian ini akan mengkaji pembuatan sistem peringatan bencana kebakaran berbasis Twitter dengan melakukan data mining pada tweet yang dibuat oleh pengguna Twitter. Tools yang digunakan adalah bahasa pemrograman Python beserta librarynya, yaitu Tweepy, Scrapy, NLTK dan lainnya. Informasi bencana kebakaran akan ditampilkan dalam tampilan peta geografis. Prototipe mesin ini dibuat dan diimplementasikan untuk wilayah Provinsi DKI Jakarta. Secara spesifik dalam lingkup media sosial, Jakarta dikenal sebagai kota dengan pengguna Twitter paling aktif, mengalahkan New York di Amerika Serikat, Tokyo di Jepang, London di Inggris Raya, dan juga Sao Paulo sebagai kota terbesar di Brasil (Lipman, 2012). Guna memaksimalkan fungsi pemerintah dalam memberikan pelayanan publik dalam penanggulangan bencana kebakaran secara efektif sehingga dapat meminimalisir dampaknya, sistem peringatan bencana kebakaran berbasis Twitter menampilkan peta realtime lokasi indikasi kejadian kebakaran berdasarkan data mining pada Twitter.

Berikut adalah tahapan proses pembuatan sistem peringatan real-time bencana kebakaran dalam penelitian ini:

1.Pengumpulan data/Data Collecting; merupakan kegiatan mengumpulkan seluruh data yang 
dibutuhkan dalam penelitian. Pengumpulan data Twitter dilakukan dengan metode streaming melalui Application Programming Interface (API) Twitter. Untuk mendapatkan akses terhadap API Twitter, dibutuhkan beberapa syarat dan ketentuan dari Twitter agar mendapatkan kunci akses dan token. Data dikumpulkan menggunakan bahasa pemrograman Python. Data yang dikumpulkan merupakan tweet hasil pencarian untuk kata kunci 'kebakaran'. Terdapat sedikit perbedaan dalam proses pemetaan dari data tweet di masa lalu dengan data tweet yang digunakan dalam sistem real-time. Pengumpulan data pada masa lalu tidak dikumpulkan dengan metode streaming seperti pada data realtime, melainkan scraping, karena data tersebut sudah tersedia sejak lampau. Selain itu, pendataan dilakukan dengan memperhatikan lokasi tweet. Data yang dikumpulkan untuk penelitian ini terbatas pada tweet yang dibuat dan terdeteksi di wilayah Provinsi DKI Jakarta. untuk memastikan bahwa data yang dikumpulkan tersebut siap digunakan untuk analisis lebih lanjut. Tahap preprocessing dilakukan dalam bentuk perbaikan format data dan pengecekan nilai yang hilang (missing value).

3.Pengolahan Teks/Text processing dilakukan dengan menggunakan metode natural language processing untuk mendapatkan intisari atau ringkasan dari setiap variabel teks pada data tweet. Text processing dimulai dengan beberapa bentuk pengolahan teks, yaitu case folding, stemming, filtering, tokenizing, dan vectorizing.

4.Klasifikasi/Classification data dilakukan untuk membedakan data tweet yang mengindikasikan adanya kebakaran dan tidak. Metode klasifikasi yang digunakan adalah Support Vector Classifier. Support Vector Classifier atau Support Vector Machine (SVM) adalah bagian dari metode supervised learning yang digunakan untuk klasifikasi dan regresi (Sain \& Vapnik, 1996). Kelebihan metode SVM adalah meminimalkan kesalahan klasifikasi empiris dan memaksimalkan margin geometrik, sehingga SVM dikenal sebagai Maximum Margin Classifiers. SVM didasarkan pada Structural Risk Minimization (SRM). SVM memetakan vektor input ke ruang dimensi yang lebih tinggi tempat maximal separator hyperplane dibuat. Dua hyperplanes paralel dibangun di setiap pemisah adalah hyperplane yang memaksimalkan jarak antara dua hyperplanes paralel. Asumsi dibuat hyperplanes paralel ini, semakin baik kesalahan
2.Pengolahan Data/Data preprocessing dilakukan sisi hyperplane yang memisahkan data. Hyperplane bahwa semakin besar margin atau jarak antara

generalisasi klasifikasinya (classifier general-ization error).

5.Pengolahan Data Spasial/Spatial Data Processing; Dari data twitter yang diperoleh, variabel lokasi yang dapat digunakan dari tweet yang dibuat oleh pemilik akun Twitter adalah bujur/longitude dan lintang/ latitude atau wilayah tertentu dari variabel lokasi Kota, yang dapat digunakan sebagai dasar pembuatan peta geografis tematik untuk melihat bagaimana sebaran kebakaran.

Selanjutnya dilakukan analisis SWOT untuk mengevaluasi kinerja sistem peringatan ini melalui kekuatan, kelemahan, ancaman dan peluang yang terbentuk. SWOT merupakan alat analisis dan pengembangan yang berguna untuk membantu melaksanakan sebuah pemikiran/rancangan (Sarsby, 2016). Dengan Matriks SWOT, gambaran yang jelas tentang strategi pengembangan sistem peringatan ini dapat dibentuk mengingat peluang dan ancaman eksternal yang dihadapi dapat disesuaikan dengan kekuatan dan kelemahan internalnya.

\section{HASIL DAN PEMBAHASAN}

\section{Data yang Dikumpulkan}

Data Twitter yang dikumpulkan dalam penelitian ini merupakan tweet dengan kata kunci 'kebakaran' yang dikumpulkan sejak 1 Januari 2018 hingga 30 September 2018 yang diperoleh menggunakan metode pengumpulan data scraping. Tabel 1 merupakan variabel yang didapatkan dari data yang berhasil dikumpulkan, beserta deskripsinya.

Tabel 1. Variabel data yang dikumpulkan Table 1. Variable data collected

\begin{tabular}{|c|c|c|}
\hline No. & Variabel & Deskripsi \\
\hline 1. & id & $\begin{array}{l}\text { Indeks unik untuk } \\
\text { identifikasi tweet }\end{array}$ \\
\hline 2. & id_user & $\begin{array}{l}\text { Indeks unik untuk identifikasi } \\
\text { pengguna }\end{array}$ \\
\hline 3. & created_at & $\begin{array}{l}\text { Tanggal dan waktu } \\
\text { tweet dibuat }\end{array}$ \\
\hline 4. & Longitude & $\begin{array}{l}\text { Derajat bujur posisi tweet } \\
\text { dibuat }\end{array}$ \\
\hline 5. & latitude & $\begin{array}{l}\text { Derajat lintang posisi tweet } \\
\text { dibuat }\end{array}$ \\
\hline 6. & country & Negara di mana tweet dibuat \\
\hline 7. & city & Kota di mana tweet dibuat \\
\hline 8. & full text & Konten/isi tweet \\
\hline
\end{tabular}

JURNAL RISET JAKARTA, Vol. 13, No 2, NOVEMBER 2020, Hal. 95-104 
Dalam periode pengumpulan data tersebut, sebanyak 24.803 tweet yang mengandung kata 'kebakaran' berhasil dikumpulkan. Berdasarkan tahapan preprocessing yang telah dilakukan, tidak semua tweet memenuhi kebutuhan penelitian. Sebanyak 22.073 tweet tidak digunakan dalam penelitian ini. Sisanya, yaitu tweet yang digunakan dalam penelitian ini, dibagi menjadi dua jenis kelompok data, training datasets dan testing datasets. Tweet yang dimasukkan ke dalam training datasets sebanyak 80 persen dari keseluruhan data yang dilibatkan dalam penelitian, digunakan untuk membangun model SVM, untuk mengklasifikasikan tweet yang mengandung kebakaran dan yang bukan. Sedangkan sisanya, sebanyak 20 persen sebagai testing datasets digunakan untuk menguji akurasi model klasifikasi yang terbentuk.

\section{Sistem Peringatan}

Dalam tweet yang mengandung kata 'kebakaran', beberapa benar-benar mengindikasikan kejadian kebakaran, namun sebagian lagi tidak. Secara teknis, untuk menentukan klasifikasi tweet yang mengindikasikan kebakaran dan yang tidak secara otomatis, digunakan model machine learning. Metode yang digunakan adalah Support Vector Classifier (SVM).

Setelah itu, tweet dibagi menjadi dua kelompok atau datasets, untuk training datasets dan testing datasets. Mesin akan mempelajari dan membangun model berdasarkan training datasets. Setelah model terbentuk dengan menggunakan SVM, maka perlu dilakukan pengujian keakuratannya dalam memprediksi apakah suatu tweet menunjukkan adanya kebakaran atau tidak dengan menggunakan testing datasets.
Tabel 2. Contoh hasil tahapan text processing tweet Table 2. Examples of the results of the text processing stage of a tweet

Tweet asli

Kebakaran Landa Bangunan di Jalan Joglo Raya Jakarta Barat. Sebuah bangunan yang berada di Gang Langgar Jalan Joglo Raya Kawasan Kembangan Jakarta Barat ludes terbakar

Hasil text processing

['bakar', 'landa', 'bangun', 'jalan', 'joglo', 'raya', 'jakarta', 'barat', 'buah', 'bangun', 'ada', 'gang', 'langgar', 'jalan', 'joglo', 'raya', 'kawasan', 'kembang', 'jakarta', 'barat', 'ludes', 'bakar']

Tabel 3. Hasil prediksi model Table 3. Model prediction results

\begin{tabular}{|c|c|c|c|}
\hline & & Predi & \\
\hline & & True & False \\
\hline Observed & True (Benar) & $\begin{array}{l}73 \\
(\mathrm{TP})\end{array}$ & $\begin{array}{l}9 \\
(\mathrm{FN})\end{array}$ \\
\hline & False (Salah) & 30 & 434 \\
\hline & & (FP) & $(\mathrm{TN})$ \\
\hline & Ukuran Keakuratan & & \\
\hline Akurasi & $(\mathrm{TP}+\mathrm{TN}) /(\mathrm{TP}+\mathrm{FP}+\mathrm{FN}+\mathrm{TN}$ & & \\
\hline Precision & $\mathrm{TP} /(\mathrm{TP}+\mathrm{FP})$ & & \\
\hline Recall & $\mathrm{TP} /(\mathrm{TP}+\mathrm{FN})$ & & \\
\hline F1-score & $\begin{array}{l}2 *(\text { Precision } * \text { Recall }) / \\
(\text { Precision }+ \text { Recall })\end{array}$ & & \\
\hline
\end{tabular}

Berdasarkan pengujian, diperoleh bahwa hasil evaluasi

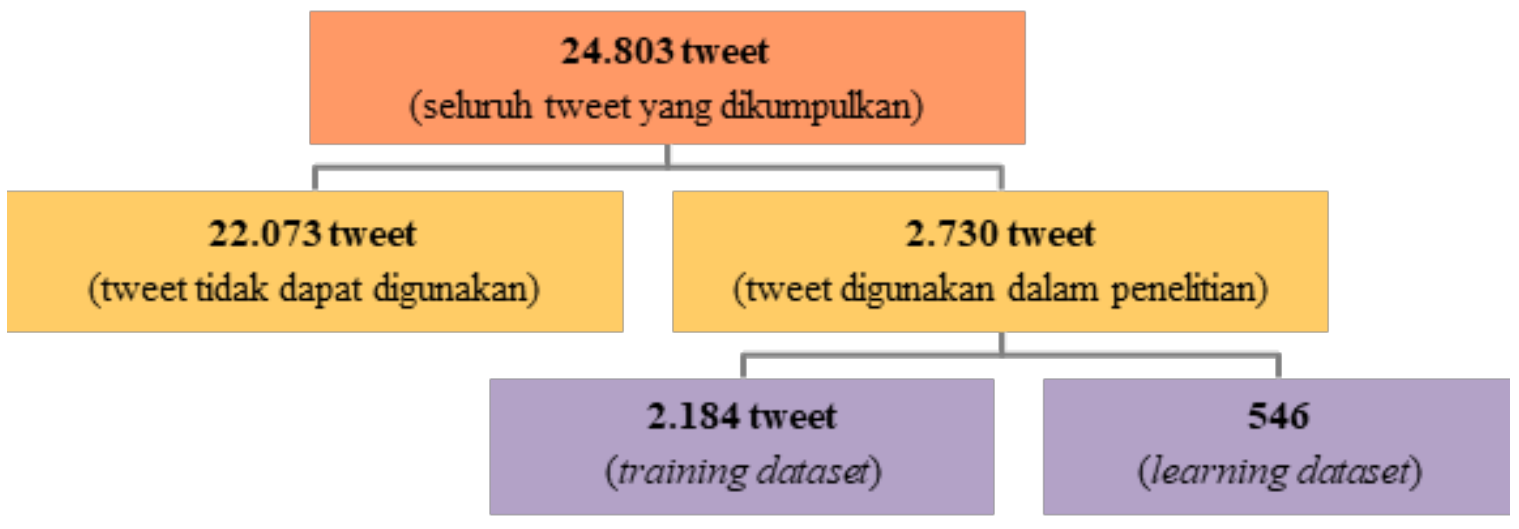

Gambar 3. Ilustrasi data yang dikumpulkan dan digunakan dalam penelitian.

Figure 3. Illustration of data collected and used in research. 
model adalah skor akurasi sebesar 0,89 , precision 0,89 , recall 0,71 , dan $F 1$-score 0,79 , di mana skor 1 merepresentasikan akurasi sempurna. Skor akurasi sebesar 0,89 menunjukkan bahwa model SVM dalam penelitian ini mampu menebak klasifikasi 89 persen dari tweet yang masuk ke dalam testing datasets dengan benar. Hasil evaluasi ini menunjukkan bahwa model yang dibangun sudah cukup baik untuk digunakan dalam mengklasifikasikan tweet mana yang mengindikasikan kebakaran dan yang tidak.

Penelitian ini juga membandingkan hasil prediksi model dengan data kebakaran yang dikumpulkan secara manual oleh Badan Penanggulangan Bencana Daerah (BPBD) DKI Jakarta. BPBD menyusun peta kejadian kebakaran di Jakarta setiap bulannya, biasanya kemudian dirilis pada awal bulan selanjutnya. Peta kejadian kebakaran yang dibuat dengan hasil data mining di Twitter dibandingkan dengan peta kebakaran yang dirilis oleh BPBD Jakarta. Kesamaan pola dari kedua hasil pemetaan tersebut juga akan sangat penting untuk mengetahui kebaikan model.

Peta kejadian kebakaran yang terakhir dirilis oleh BPBD Jakarta dalam Sistem Informasi Geospasial (http://gis.bpbd.jakarta.go.id) sampai dengan akhir tahun 2019, adalah peta kejadian kebakaran pada bulan September 2018. Berdasarkan Gambar 4, sebagian besar kebakaran di Jakarta pada bulan September 2018 terjadi secara merata di kota-kota administratif di wilayah daratan Provinsi DKI Jakarta. Dua peta di atas menunjukkan pola sebaran api yang hampir sama. Untuk memastikan kesamaan polanya, dibuat peta kejadian kebakaran berdasarkan data mining Twitter pada bulan-bulan lainnya. Pada Gambar 5 ditampilkan perbandingan peta kejadian kebakaran bulan Januari 2018 hasil data mining Twitter yang dihasilkan penelitian ini dengan peta konvensional yang dikeluarkan BPBD DKI Jakarta.

Kebanyakan kebakaran pada bulan Januari 2018 terjadi di wilayah Kota Administratif Jakarta Utara dan Pusat. Kedua peta tersebut masih cenderung menunjukkan pola sebaran kejadian kebakaran yang sama. Melalui perbandingan terhadap beberapa periode waktu yang berbeda, secara umum, peta dari data konvensional dengan peta dari data mining Twitter memiliki pola yang sama dalam menunjukkan data kejadian kebakaran. Hal ini menunjukkan bahwa keberadaan tweet dari masyarakat dapat digunakan untuk menunjukkan kejadian dan lokasi kebakaran, sehingga dapat digunakan sebagai sebuah sistem peringatan.

Karena menggunakan data yang berasal dari tweet, sistem peringatan ini dapat menyediakan peta yang menampilkan situasi secara langsung atau realtime, karena akan secara otomatis mendeteksi kemunculan tweet-tweet dengan kata 'kebakaran' yang mengindikasikan kebakaran berdasarkan model klasifikasi. Untuk memperluas pemanfaatannya, sistem dibuat dengan bersifat terbuka dan dapat diakses oleh publik. Dengan demikian, sistem ini tidak hanya berguna bagi petugas pemadam kebakaran dalam melakukan tindakan penanganan, tetapi juga memberikan informasi kepada pengguna jalan agar berhati-hati saat berada di sekitar lokasi kebakaran.

Desain antarmuka pengguna (user interface) dari
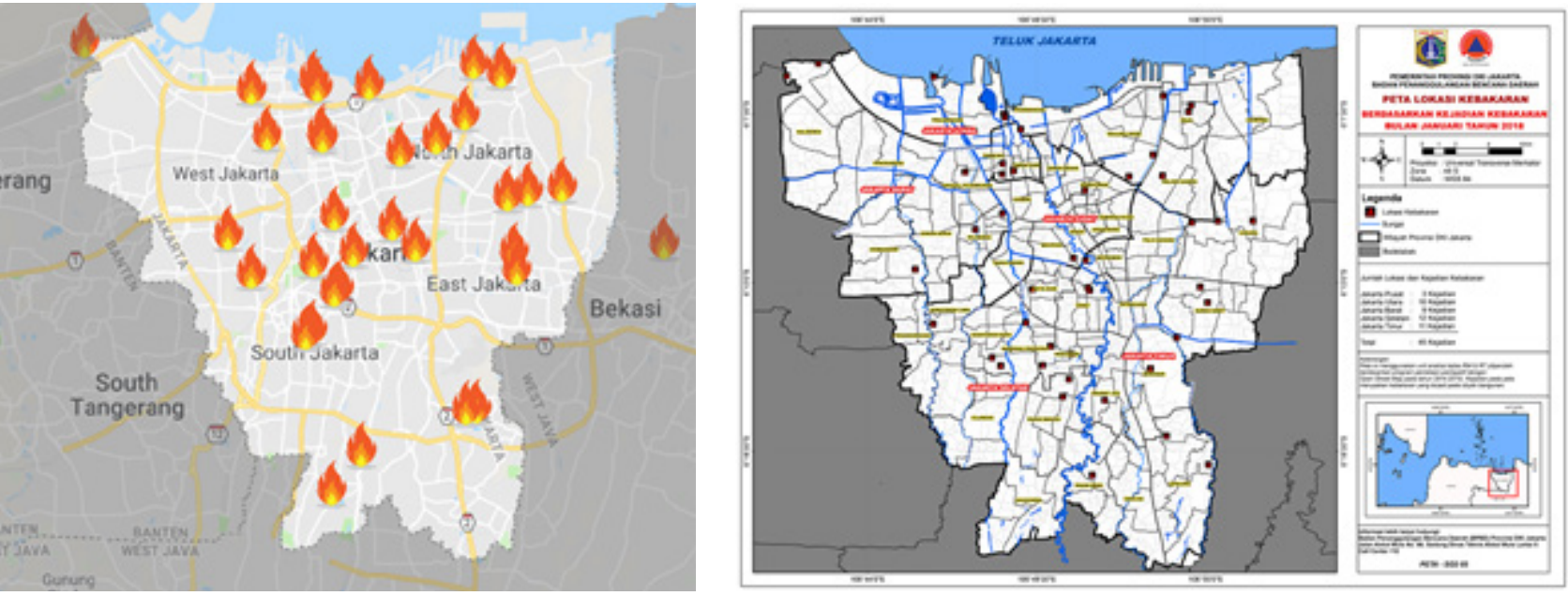

Gambar 4. Peta kejadian kebakaran berdasarkan data mining Twitter (kiri) dan BPBD (kanan) Bulan September 2018 (BPBD DKI Jakarta, 2018).

Figure 4. Map of fire events based on Twitter data mining (left) and BPBD (right) September 2018 (BPBD DKI Jakarta, 2018). 

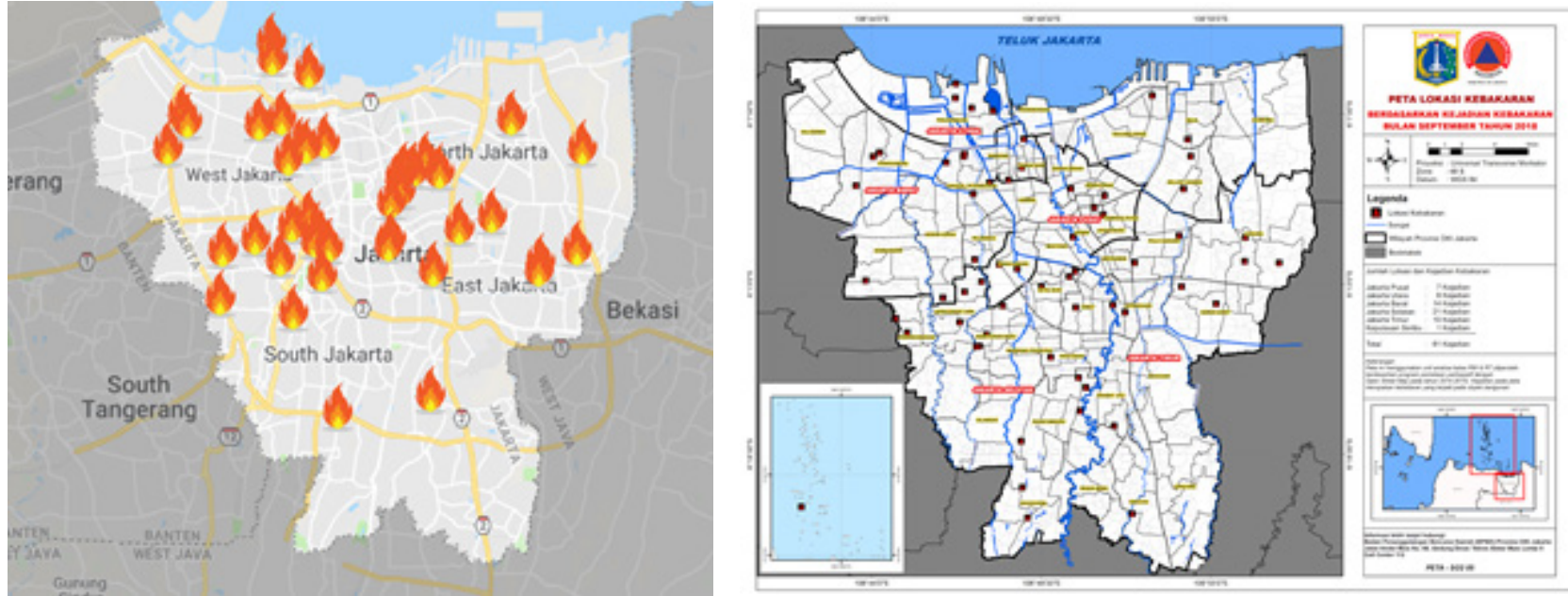

Gambar 5. Peta kejadian kebakaran berdasarkan data mining Twitter (kiri) dan BPBD (kanan) Bulan Januari 2018 (BPBD DKI Jakarta, 2018).

Figure 5. Map of fire events based on data mining Twitter (left) and BPBD (right) January 2018 (BPBD DKI Jakarta, 2018).

sistem yang terbentuk ditunjukkan pada Gambar 6. indikasi kejadian kebakaran.

Sistem mampu memberikan lokasi yang akurat dengan koordinat. Hal ini memudahkan pihak Pemadam Kebakaran untuk menuju lokasi dengan rute paling efektif dibantu oleh Google Maps Routing karena kemacetan lalu lintas biasanya terjadi pada sebagian besar rute di perkotaan. Selain itu, sistem peringatan ini juga dapat menyediakan fitur pelaporan otomatis yang dapat disesuaikan. Fitur pelaporan kejadian kebakaran dapat diakses melalui web atau Twitter. Fitur pelaporan insiden kebakaran merupakan kombinasi teknologi dengan Twitter dan media sosial web. Laporan melalui twitter dapat dilakukan dengan membuat tweet yang disertai dengan hashtag khusus akan langsung dibaca oleh sistem secara real-time sebagai tweet yang mengindikasikan kebakaran dengan metode streaming melalui API Twitter. Selanjutnya sistem memberi tahu

\section{SWOT Analysis}

Terkait evaluasi dan pengembangan sistem, dilakukan analisis dengan menggunakan matriks SWOT sebagai teknik pembuatan kajian strategis yang meliputi penentuan tujuan proyek serta identifikasi faktor internal dan eksternal yang mempengaruhi ketercapaian tujuan tersebut. Faktor internal tersebut terdiri dari kekuatan (strength) dan kelemahan (weakness) proyek yang dihasilkan, sedangkan faktor eksternal diharapkan dapat memberikan ancaman (threat) dan peluang (opportunity) bagi keberlangsungan proyek Sebelumnya, telah dijabarkan bahwa sistem peringatan ini menyediakan data real-time karena mendeteksi lokasi real-time tweet yang berisi kata kunci yang telah ditentukan.

Dinas Kebakaran terdekat beserta koordinat lokasi

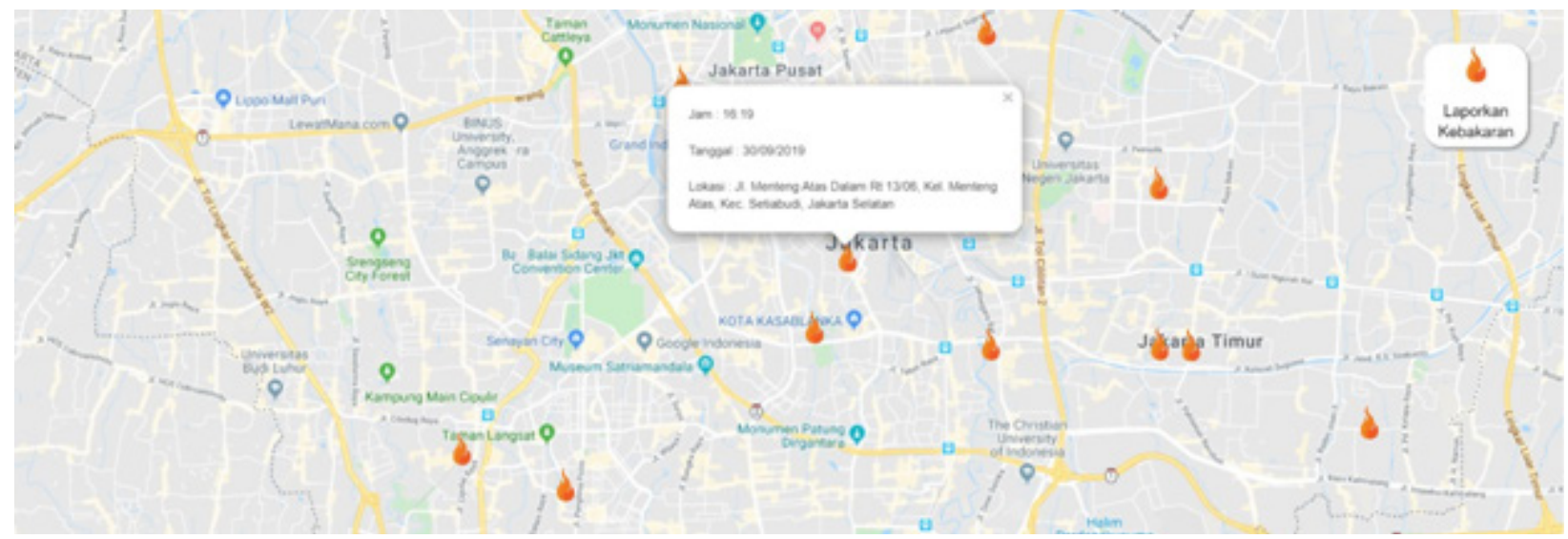

Gambar 6. Desain antarmuka pengguna dari sistem peringatan real-time hasil data mining Twitter.

Figure 6. User interface design of Twitter's real-time data mining results alert system. 

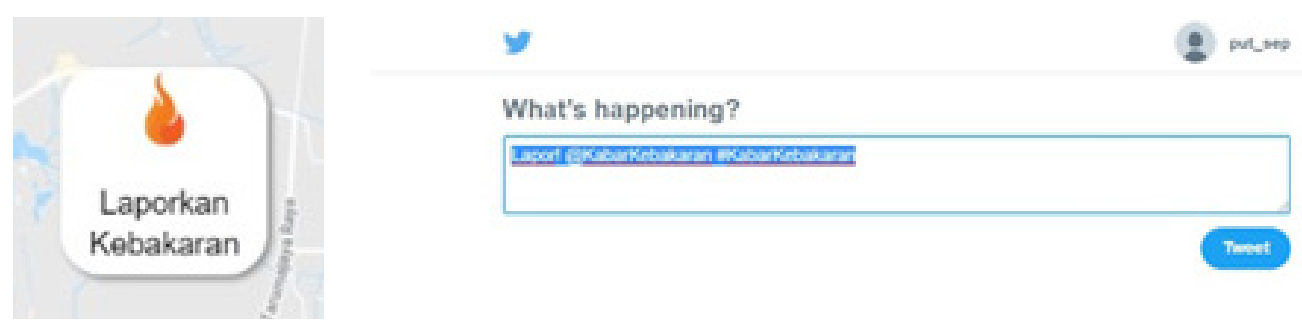

Gambar 7. Fitur pelaporan.

Figure 7. Reporting features.

Informasi ini merupakan keunggulan sistem ini, sehingga Dinas Pemadam Kebakaran DKI Jakarta dapat segera mengambil keputusan yang harus segera diambil. Informasi berbasis geografis juga dapat digunakan sebagai bahan untuk mengambil rute tercepat dan paling efisien untuk mencapai titik api (hotspot). Selain itu, karena sistemnya terbuka dan dapat diakses oleh siapa saja, masyarakat dapat menggunakan sistem ini untuk menghindari wilayah yang terkena bencana kebakaran, yang sangat berpotensi menimbulkan kerumunan dan kemacetan.

Sayangnya, sistem ini masih mengandung kelemahan utamanya pada keakuratan informasi yang diberikan karena hanya berbasis kata. Masih terdapat bias antara maksud yang terkandung di setiap kata yang digunakan dalam tweet pengguna. Sedangkan dari sisi eksternal, sistem ini berpeluang untuk berkembang pemanfaatannya karena penetrasi internet Kota Jakarta semakin meningkat. Namun terdapat ancaman berupa penyalahgunaan sistem ini oleh masyarakat dengan mengumpulkan tweet dengan kata kunci yang telah ditentukan sehingga terdeteksi sebagai indikasi adanya kebakaran. Dari kekuatan, kelemahan, peluang dan ancaman yang diharapkan tersebut, dapat dibentuk matriks SWOT untuk menentukan strategi yang dapat diterapkan.

Strategi yang dapat dilakukan oleh pemerintah dalam mengembangkan sistem ini berdasarkan analisis SWOT dapat dilihat pada Tabel 4. Bagaimanapun, peluang penggunaan big data terutama di perkotaan dengan penetrasi internet yang tinggi, sangatlah besar. Pemerintah sebagai pembuat kebijakan melalui jajaran instansi terkait dapat mulai memanfaatkan kesempatan ini dalam rangka memaksimalkan pelayanan publik dengan melibatkan masyarakat itu sendiri melalui data yang mereka hasilkan di media sosial. Informasi yang real-time dapat menjadi bahan pengambilan keputusan yang cepat dan akurat, sehingga dapat meminimalisir

Tabel 4. Matrisk SWOT sistem peringatan dini real-time berbasis Twitter

Table 4. Matrisk SWOT, Twitter-based real-time early warning system

\begin{tabular}{|c|c|c|}
\hline & $\begin{array}{l}\text { Strengths: } \\
\text { - Data dikumpulkan secara langsung } \\
\text { (real-time) } \\
\text { - Data berbasis geografis/lokasi }\end{array}$ & $\begin{array}{l}\text { Weakness } \\
\text { - Bias mana yang terdeteksi } \\
\text { dari kata di dalam tweet }\end{array}$ \\
\hline $\begin{array}{l}\text { Opportunity: } \\
\text { - Penetrasi internet di wilayah perkotaan } \\
\text { lainnya terus tumbuh secara progresif }\end{array}$ & $\begin{array}{l}\text { Strategy }(\boldsymbol{S}-\boldsymbol{O}) \text { : } \\
\text { - Membuat sistem peringatan untuk } \\
\text { wilayah perkotaan lainnya di Indonesia }\end{array}$ & $\begin{array}{l}\text { Strategy }(\boldsymbol{W}-\boldsymbol{O}) \text { : } \\
\text { - Sosialisasi kepada masyarakat } \\
\text { untuk terlibat dalam pelaporan } \\
\text { setiap kejadian kebakaran }\end{array}$ \\
\hline $\begin{array}{l}\text { Threat: } \\
\text { - Penyalahgunaan oleh pihak yang } \\
\text { tidak bertanggung jawab }\end{array}$ & $\begin{array}{l}\text { Strategy }(\boldsymbol{S}-\boldsymbol{T}) \text { : } \\
\text { - Pemberlakuan sanksi }\end{array}$ & $\begin{array}{l}\text { Strategy }(\boldsymbol{W}-\boldsymbol{T}) \text { : } \\
\text { - Penggunaan aturan validasi } \\
\text { yang lebih ketat dengan SVM } \\
\text { atau metode natural language } \\
\text { processing lainnya dalam } \\
\text { mendeteksi tweet }\end{array}$ \\
\hline
\end{tabular}


dampak, baik korban jiwa maupun kerugian materi baik dari pihak pemerintah maupun masyarakat.

\section{KESIMPULAN DAN SARAN}

Sistem peringatan real-time bencana kebakaran yang dibangun menggunakan model SVM dapat mengklasifikasikan tweet yang mengindikasikan kebakaran dengan kata kunci 'kebakaran' dengan cukup baik. Akurasi model SVM ini adalah 0,89. Hasil pemetaan indikasi kebakaran hasil data mining di Twitter periode Januari dan September 2018 juga menunjukkan pola yang serupa dengan data peta bencana kebakaran konvensional. Hal ini menunjukkan bahwa sistem peringatan ini dapat dimanfaatkan sebagai sebuah sistem peringatan resmi yang realtime dan dapat meningkatkan efektivitas kinerja pemadam kebakaran khususnya dalam menjangkau lokasi kebakaran. Namun berdasarkan analisis matriks SWOT, masih terdapat kelemahan dan ancaman dari sistem peringatan ini. Banyak kebijakan pemerintah yang perlu diterapkan untuk mengiringi penggunaan sistem ini, terutama dalam meningkatkan keamanan dan validasi sistem untuk mencegah penyalahgunaan.

\section{UCAPAN TERIMA KASIH}

Ucapan terima kasih ke semua pihak yang telah membantu terlaksananya seluruh kegiatan penelitian sampai selesai.

\section{DAFTAR PUSTAKA}

AAdedoyin-Olowe, M., Gaber, M. M., Dancausa, C. M., \& Stahl, F. (2014). Extraction of unexpected rules from twitter hashtags and its application to sport events. Proceedings - 2014 13th International Conference on Machine Learning and Applications, ICMLA 2014, January, 207212. https://doi.org/10.1109/ICMLA.2014.38

Antara. (2019). Kerugian Kebakaran di Jakarta Sepanjang Tahun Ini Rp 137,8 Miliar. Tempo. https://metro.tempo.co/read/1215966/kerugiankebakaran-di-jakarta-sepanjang-tahun-ini-rp1378-miliar/full\&view=ok Akses 18 Juni 2019.

Badan Pusat Statistik. (2018). Statistik Telekomunikasi Indonesia 2017. https://www.bps.go.id/ publication/download.

BPBD DKI Jakarta. (2018). Peta Kebakaran Bulan
September 2018. GIS BPBD DKI Jakarta. http:// gis.bpbd.jakarta.go.id/documents/593

Brodie, C. (2017, May 22). These are the World's Most Crowded Cities. World Economic Forum. https://www.weforum.org/agenda/2017/05/ these-are-the-world-s-most-crowded-cities/

Ismawan, D. A. (2008). Kajian Kerentanan Kawasan Permukiman Padat Terhadap Bencana Kebakaran di Kecamatan Tambora Jakarta Barat [University of Diponegoro]. http://eprints.undip. ac.id/4074/

Jago, N. (2013). Gerakan Kota Hijau. PT Gramedia Pustaka Utama.

Kalyvas, J. R., \& Overly, M. R. (2015). Big Data: A Business and Legal Guide. CRC Press.

Lipman, V. (2012, December 30). The World's Most Active Twitter City? You Won't Guess It. Forbes. https://www.forbes.com/ sites/victorlipman/2012/12/30/the-worldsmost-active-twitter-city-you-wont-guessit/\#22ec291955c6

McNab, C. (1970). World's Worst Historical Disaster. The Rosen Publishing Group, Inc.

Mejía-d, \& Dugand, S. (n.d.). Environmental Technology and its Role in the Search for Urban Environmental Sustainability : The Dynamics of Adaptation (Issue 1659) [Linköping University]. https://www.diva-portal.org/smash/get/ diva2:812392/FULLTEXT01.pdf

Sain, S. R., \& Vapnik, V. N. (1996). The Nature of Statistical Learning Theory. Technometrics. https://doi.org/10.2307/1271324

Sarsby, A. (2016). SWOT Analysis. Lulu.com. https:// www.lulu.com/shop/alan-sarsby/swot-analysis/ paperback/product-22932529.html

Setiawan, R. (2019, July 11). Kebakaran di Wilayah Padat Jakarta: Ancaman Maksimal, Miskin Solusi. Tirto. https://tirto.id/kebakaran-diwilayah-padat-jakarta-ancaman-maksimalmiskin-solusi-ed4y

Sorensen, A., \& Okata, J. (2011). Megacities: Urban Form, Governance, and Sustainability. Springer 
Verlag. https://doi.org/10.1007/978-4-43199267-7

Thangavel, C., Jayapal, P., \& Kulkarni, K. M. (1987). Spatial Pattern of some Infectious Diseases: A Case Study of Ahmedabad City. In C. S. Yadav (Ed.), Perspective in Urban Geography (Vol. 8, Issue Contemporary Urban, pp. 235-252). Concept Publishing Company. https://books. google.co.id/books?id=FKrfnnncOFkC\&prints $\mathrm{ec}=$ frontcover $\& \mathrm{hl}=\mathrm{id} \# \mathrm{v}=$ onepage $\& \mathrm{q} \& \mathrm{f}=$ false

TomTom. (2019). TomTom Traffic Index: Mumbai takes Crown of 'Most Traffic Congested City' in World. In TomTom Traffic Index. https://library. tomtom.com/share/0E286C8F-F2E0-4422923E8D1B7C5F2B61/?mediaId=4C386BE9E2B0-4691-99440A38CAD754A3\%0Ahttp:// corporate.tom tom.com/releasedetail. cfm?releaseid $=961546$

UN, (United Nations). (2018a). The World 's Cities in 2018-Data Booklet. In United Nations, Department of Economic and Social Affairs, Population Division. https://www.un.org/en/ events/citiesday/assets/pdf/the_worlds_cities in_2018_data_booklet.pdf

Yayasan Peta Bencana. (n.d.). Petabencana.id. Retrieved from https://petabencana.id/map/ Daerah\%20Khusus\%20Ibukota\%20Jakarta

UN, (United Nations). (2018b). World Urbanization Prospects. In Demographic Research, 12. https:// doi.org/10.4054/ demres.2005.12.9 